\title{
Landmark Legislation Ensuring Equality for People with HIV/AIDS in India: An Appraisal
}

\author{
Mary Mathew \\ Professor of Pathology, Kasturba Medical College, Manipal, Manipal Academy of Higher Education, \\ Manipal, Karnataka, India \\ Corresponding Author : Mary Mathew \\ E-mail: marymathew883@gmail.com
}

\begin{abstract}
People with HIV-AIDS are subjected to a wide variety of discriminatory practices and are denied basic health care needs. India has a high population of people living with HIV whose rights and human dignity has not been acknowledged. In 2014, a new bill was introduced in parliament to address these concerns and prevent the spread and control of HIV in India. After nearly 3 years, passing of this 'people-centric' bill unanimously by the parliament is a constitutional victory for our country. This article is an appraisal of this landmark bill which seeks to remove social stigma associated with the disease and criminalize discrimination against this vulnerable community.
\end{abstract}

Key words: ethics, equality, HIV, landmark, legislation

\section{INTRODUCTION}

India has the third largest Human Immunodeficiency Virus (HIV) epidemic in the world. The United Nations AIDS office estimates that as of 2017, about 2.1 million people were living with HIV in India and 68,000 had died of the disease. The adult HIV prevalence is $0.3 \%$ with 80,000 new HIV infection and 62,000 AIDS related deaths. Currently, 50\% adults and 33\% children are on antiretroviral treatment and estimates show that one million people in India are receiving treatment for HIV infection. The epidemic though heterosexual sex driven is largely confined to high risk individuals, such as female sex workers but includes men in sexual relationships with other men, and intravenous drug users [1].

This disease is fraught with numerous legal and ethical issues such as confidentiality and disclosure, employment and disability rights and accessibility to medical care. More importantly, people living with HIV and AIDS experience high levels of discrimination and issues of social stigma and human dignity that result in grave consequences. A new legislation in India has been introduced to remove these barriers and empower people living with HIV/AIDS and help in challenging violations of human rights.

\section{THE NEW BILL}

On April 24, 2017, Pranab Mukherjee, the President of India at the time, approved a new legislation that bans discrimination against people who are HIV-positive or who have Acquired Immunodeficency Syndrome (AIDS). The Human Immunodeficiency Virus (HIV) and Acquired Immunodeficiency Syndrome (Prevention and Control) Bill 2017, guarantees equal rights in medical treatment, admission to education institutions and employment. The law provides a broad legislative framework for HIV in India and is the first of its kind in South Asia. 
This 'people-centric' Bill is an indication of the government's commitment to strengthen the rights of people with HIV and ensures free treatment.

This extensive legislation has 50 clauses, arranged in 14 chapters that cover a number of topics, including penalties for violation of its provisions.

It addresses the issue of stigma faced by people with HIV and AIDS, ensures confidentiality and privacy while providing HIV and AIDS related services and strengths the existing National AIDS Control Programme by bringing in legal accountability. Existing establishments, both private and public are called to recognize the need to safeguard the rights of people infected with HIV/AIDS, particularly, women and children.

Within the ambit of this Bill is the provision that makes anti-retroviral therapy, a legal right of people with HIV/AIDS and states that "every person in the care and custody of the state shall have the right to HIV prevention, testing, treatment and counseling services." The central and state governments are mandated to provide treatment, infection management and facilitate access to welfare schemes. An important and notable feature in the Bill is the clause that specifies that HIV testing, treatment, and status disclosure require informed consent. No person shall have to undergo HIV testing or medical treatment without an informed consent. However, screening in licensed blood banks and medical research where the testing is anonymous does not require an informed consent.

The Bill had added provisions that count as discriminatory practice against people with HIV which include denial or discontinuation of employment, education, renting or residing property, standing for public or private office and health care. The Bill prohibits HIV testing as a perquisite for obtaining employment, health care services and education [2]. This law also ensures the right to access to insurance and freedom of movement. In keeping with the principle of ensuring human dignity, this law bans unfair treatment of people with HIV with regard to access of public facilities such as shops, restaurants, hotels, public entertainment venues and burial grounds. The Bill gives minors with HIV, the right to live in a shared household and prohibits people from inciting hatred against them.

There are clauses establishing safe working environments; and measures on the creation of mechanisms to redress grievances and investigate complaints [3]. The Bill provides provision for fast tracking of cases by the court related to HIV positive persons on a priority basis. Regarding dealing of such cases, the court may pass orders to ensure confidentiality during proceedings by suppressing the identity of the person/ or to conduct in camera and to restrain from publishing information that discloses the identity of the person [4].

\section{PENALTIES}

The penalties established in the Bill include imprisonment from three months to two years and/or a fine of up to 100,000 rupees (about US $\$ 1,550$ ) for persons convicted of publicly advocating hatred, discrimination, or violence against protected persons or propagating feelings likely to expose them to hatred, discrimination, or violence. Disclosing the HIV status of a protected person is also subject to a 100,000 rupee fine. The Bill defines protected persons as those who are HIV-positive or who ordinarily live or did live with a person who is HIV-positive. An important provision of the legislation is the prohibition of mistreatment of whistleblowers in cases related to the issue of treatment of those with HIV or AIDS. The protection covers people who make complaints, bring proceedings, give information, or serve as witnesses in related proceedings [5].

\section{CONCLUSION}

This landmark legislation on HIV/AIDS is a complete expression of the exercise of fundamental rights of every person as declared in the Constitution of India. This Bill ensures equality, justice and human dignity at the same providing protection for this vulnerable community. 


\section{REFERENCES}

1. http://www.unaids.org/sites/default/files/media_asset/20170720_Data_book_2017_en.pdf

2. http://indianexpress.com/article/what-is/hiv-aids-bill-passed-parliament-lok-sabha-naddadiscrimination-4611167/

3. http://www.thehindu.com/news/national/parliament-clears-landmark-hivbill/article17930015.ece

4. https://timesofindia.indiatimes.com/india/rajya-sabha-passes-bill-to-ensure-rights-of-hiv-and-aidspatients/articleshow/57756483.cms

5. http://www.prsindia.org/uploads/media/HIV/HIV-AIDS\%20Bill,\%202014.pdf

Acknowledgements - Nil

Source of Funding - Nil

Conflict of Interest - Nil 